\title{
NUMERICAL ANALYSIS OF LIQUEFACTION PHENOMENON BY USING UBC3D-PLM CONSTITUTIVE MODEL
}

\author{
Ahmed Moussa Abu Bakr ${ }^{1}$, Ahmed Mohamed hassan², Mohamed Abd El Fattah ${ }^{3}$, \\ Amr Mohey Mohamed ${ }^{4}$ \\ ${ }^{1}$ Associate Professor in Civil Engineering Dept., Faculty of Engineering, Minia University, \\ E-mail: ahmed.meg61@yahoo.com \\ ${ }^{2}$ Associate Professor in Civil Engineering Dept., Faculty of Engineering, Minia University, \\ E-mail: Ahmed.ismeal@mu.eg.edu \\ ${ }^{3}$ Associate Professor in Civil Engineering Dept., Faculty of Engineering, Minia University, \\ E-mail: dr.eng.m.eid@ hotmail.com \\ ${ }^{4}$ Civil engineer, \\ E-mail:eng.amrmohey@gmail.com
}

\begin{abstract}
This research is considering of numerical analysis of liquefaction phenomenon by using UBC3D-PLM constitutive model. Liquefaction is a phenomenon in which the strength and stiffness of a soil is reduced by earthquake shaking or other rapid loading. Liquefaction occurs in saturated soils, that is, soils in which the space between individual particles is completely filled with water. This water exerts a pressure on the soil particles that influences how tightly the particles themselves are pressed together. Prior to an earthquake, the water pressure is relatively low. However, earthquake shaking can cause the water pressure to increase to the point where the soil particles can readily move with respect to each other. The UBC3D-PLM is one of the most commonly used constitutive models for liquefaction problems in practice. Even though it is an advanced model, it is relatively simple to apply, since it has a reasonable number of parameters that can be extracted from laboratory or in situ tests. The model was initially developed for sand-like soils having the potential for liquefaction under seismic loading. The UBC3D-PLM model has been developed by Tsegayce (2010) and implemented as a user defined model in PLAXIS. In this research, the capability of this model is considered by using PLAXIS software. The real data of El Centro earthquake 1940, Imperial Valley earthquake 1979 and Upland earthquake 1990 were used. The results of the simulation have shown resembling trend of the UBC3D-PLM and HSSMALL models. This research compare between the results which get after earthquake on liquefied sand and strong layer (coarse sand).
\end{abstract}

\section{Keywords: Liquefaction, Soil, Stress-strain, Pore-Water pressure, UBC3DPLM, HSSMALL, Earthquake impact.}

\section{Introduction}

The liquefaction phenomena occur when the cyclic shearing of saturated granular soils causes an increase of pore water pressure which lead to a value equal to the initial confining pressures, thereby softening the soil causing large strain. This process has been termed as 'liquefaction'.

The main reason of most of the structure damages, during earthquake, is liquefaction. In recent strong earthquakes such as Alaska in year 1964, USA in year (1987), Japan in year (1995), Turkey in year (1999), Taiwan in year (1999), Iran in year (2004) and China in year (2008), many buildings, highway, embankments, and other engineering structures have been damaged or destroyed as result of liquefaction.

When the ground is subjected to strong motion or strong shaking due to earthquake, certain types of soils liquefy often leading to ground failures. Ground failure associated 
with liquefaction of soils is potentially very damaging as forcefully demonstrated by many disastrous earthquakes [1].

The stress-strain behavior of a soil depends on many factors such as the type of soil, stress-strain history, mode of deposition, anisotropy, and stress level dependency of stiffness [2], [3]. Hence, a constitutive model of soil, describes its stress-strain behavior, becomes very complicated if all the above mentioned aspects aren't included.

In (2015) Abbas Daftari, compared between Finn-Byrne model by using FLAC software and UBC3D-PLM model by using PLAXIS software [4]. Comparing the results of numerical modeling of pore water pressure and observation of pore water pressure of soil liquefaction in Wildlife area after superstition earthquake in (1987), He showed that the generation of excess pore water pressure on wildlife site was considered by using Finn-Byrne- and UBC3D-PLM model. The calculation of excess pore water pressure shows that these constitutive models can reproduce the main mechanism of liquefaction. In spite of the first relax period in Finn-Byrne model the pore water pressure generation is not smooth, but in UBC3D-PLM model pore water-pressure generation has gradual rise. The sharp generation problem in FinnByrne model was improved in UBC3DPLM model by using two yields surface in hardening process.

In this study, PLAXIS finite element program is used. The UBC3D-PLM and the HSSMALL models are used in the numerical analyses. The UBC3D-PLM is a nonlinear elastic-plastic model that is capable of capturing seismic liquefaction behavior of sands and silty sands. The HSSMALL can capture seismic behavior of soil [5]. Although the model has not been designed specifically for dynamic applications, it does have capabilities to describe dynamic soil behavior to some extent. The small-strain stiffness formulation involves the degradation of the shear stiffness with the shear strain, and it considers that the high small-strain stiffness is regained upon load reversal. When subjected to cyclic shear loading the model shows hysteresis.

\section{Materials models}

\subsection{UBC3D-PLM model}

The original UBCSAND is a 2-D model which introduced by Puebla. Beaty and Byrne can simulate the liquefaction behavior of sands and silty sands under seismic loading [6],[7]. The UBC3D is a 3-D generalized formulation of the original 2-D UBCSAND model. The initial UBC3DPLM implementation in PLAXIS was developed and presented by Tsegaye [8]. The UBC3D-PLM model, with some adjustment, has been performed as a user defined soil model in the finite element program PLAXIS [7],[9]. The PLAXIS version of the UBCSAND model is utilized in this study. The material parameters demands for the UBC3D-PLM model are mentioned in Table (1).

Alike most liquefaction models UBC3D-PLM is a descriptive model and the model parameters are determined by curve fitting, preferably from cyclic un drained direct simple shear (DSS) tests. However in many cases these tests are not available and data from in situ tests such as Standard Penetration (SPT) or Cone Penetration (CPT) tests exist. For this reason for the UBCSAND model, Beaty and Byrne have proposed certain correlations connecting the model parameters in Table (1) with the corrected clean sand equivalent SPT blow-count measurements $\left(\left(\mathrm{N}_{1}\right)_{60}\right)$ [7].

These correlations are the following:

$$
\begin{aligned}
& -k_{G}^{e}=21.7 \times 20.0 \times \\
& \left(\left(N_{1}\right)_{60}\right)^{0.333}
\end{aligned}
$$

Where $k_{G}^{e}$ is the elastic shear modulus 
$-\quad k_{B}^{e}=k_{G}^{e} \times 0.7$

Where $k_{B}^{e}$ is the elastic bulk modulus

$$
\begin{array}{ll}
- & k_{G}^{P}=k_{G}^{e} \times\left(\left(N_{1}\right)_{60}\right)^{2} \times \\
& 0.003+100.0
\end{array}
$$

Where $k_{G}^{P}$ is the plastic shear modulus

$-\Phi_{p i}=\Phi_{c v}+\frac{\left.\left(N_{1}\right)_{60}\right)}{10}$

- $\Phi_{p}=\Phi_{p i}+\max \left(0.0, \frac{\left(N_{1}\right)_{60}-15}{5}\right)(5)$

Where $\Phi_{p}$ and $\Phi_{c v}$ are peak friction angle and constant volume friction angle.

$$
-R_{f}=1.1 \times\left(\left(N_{1}\right)_{60}\right)^{-0.15}
$$

Where $R_{f}$ is the failure ratio

\subsection{The hardening soil with small- strain stiffness (HSSMALL) model}

The (HS) model is an advanced model for simulation of soil behavior [10], and it uses the Mohr-Coulomb model (MC) to describe the failure criterion. Before reaching the failure surface, the HS model adopts a hyperbolic stress-strain relation between the vertical strain and deviatoric stress for primary loading, which the wellknown model is proposed by Duncan and Chang [11]. Three different stiffness (triaxial loading secant stiffness $\mathrm{E}^{\text {ref }}{ }_{50}$, triaxial unloading/reloading stiffness $\mathrm{E}$ ref and oedometer loading tangent stiffness $\mathrm{E}$ ${ }_{\text {oed }}$ ) are used in the (HS) model to calculate the soil stiffness.

The original Hardening Soil (HS) model assumes that the materials have an elastic behavior during unloading and reloading. However, the strain range in which soils can be considered truly elastic, i.e. where they recover from applied straining almost completely, is very small. With increasing strain amplitude, soil stiffness decays nonlinearly. Figure (1) Gives an example of such a stiffness reduction curve. It turns out that at the minimum strain which can be reliably measured in classical laboratory tests, soil stiffness is often decreased to less than half its initial value.

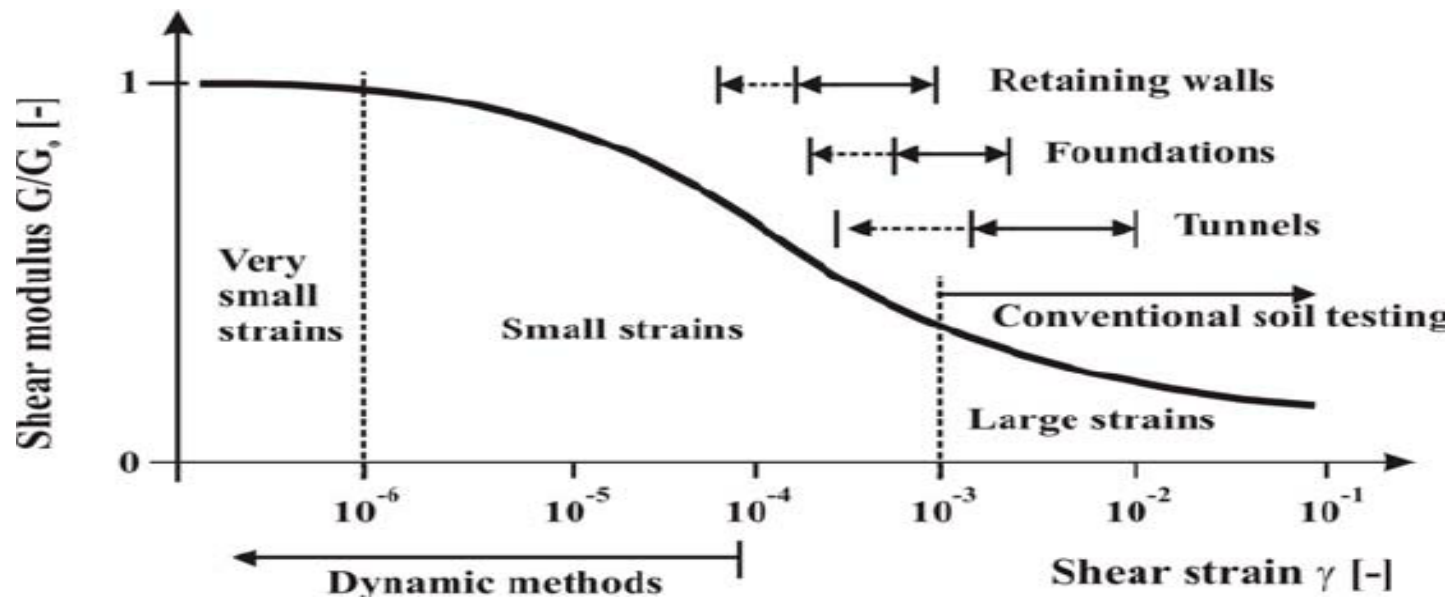

Fig . 1: Characteristic stiffness-strain behavior of soil with typical strain ranges for laboratory tests and structures (after Atkinson \& Sallfors (1991))

The HSSMALL model is adjusted from the HS model with considering the small strain characteristics of soil based on the research of Benz [12]. At very small and small strain levels, most soils show a higher stiffness than that at engineering strain 
levels. Hardin and Drnevich proposed a modified hyperbolic law for the stiffness degradation curve which is used by the (HSSMALL) model [13].

The main difference between the (HS) model and the (HSSMALL) model is the (HSSMALL) model requires two additional parameters. These two parameters are the reference shear modulus at very small strain $\mathrm{G}_{0}{ }^{\text {ref }}$ and shear strain $\gamma_{0.7}$ at which the secant shear modulus Gs is reduced to about $70 \%$ of $\mathrm{G}_{0}$. The material parameters demands for the (HSSMALL) model are,

$$
\text { - } G_{0}=\rho\left(v_{s}\right)^{2}=\frac{\gamma}{\mathrm{g}}\left(v_{s}\right)^{2}
$$

Where $\mathrm{G}_{0}$ is the shear modulus at very small strain level of sand layers and $\mathrm{G} 0{ }_{\gamma}$ is the total unit weight, $g$ is gravitational acceleration, $\mathrm{V}_{\mathrm{s}}$ is shear wave velocity in soil and $\rho$ is the total density of soil.

- $G_{0}=G_{0}{ }^{r e f}\left(\frac{\sigma 3}{\mathrm{p}}\right)^{\mathrm{m}}$

Where $\mathrm{G}_{0}{ }^{\text {ref }}$ is The reference shear modulus at very small strain level, $\sigma_{3}$ is the effective stress, $\mathrm{m}$ is the Power for stress-level dependency of stiffness and $p$ is the reference pressure that is usually taken as $100 \mathrm{kPa}$ (1 bar).

$$
\text { - } \sigma 3=\Sigma(\gamma \times h)
$$

Where $\gamma$ is the unit weight of soil and $h$ is the soil depth.

\section{Applied model}

This model represents three layers. The first layer starts from ground and extends for $5 \mathrm{~m}$, the second layer also has $5 \mathrm{~m}$ thickness blow the first layer and the third has $10 \mathrm{~m}$ thickness blow the second one. Under the third layer there is a stiff rock strata that is assumed to extend infinitely. The groundwater level lies at level $-1 \mathrm{~m}$ under the ground surface. In this research, different four cases are inveigled and three types of earthquakes effect on each case.

1- The first case assumed that the first and third layers consist of liquefied sand and the second layer consists of strong sand.

2- The second case assumed that the first, second and third layers consist of liquefied sand.

3- The third case assumed that the first and third layers consist of strong sand and the second layer consists of liquefied sand.

4- The fourth case assumed that the first, second and third layers consist of strong sand.

This research draws attention to the first case and the other cases in the master research.

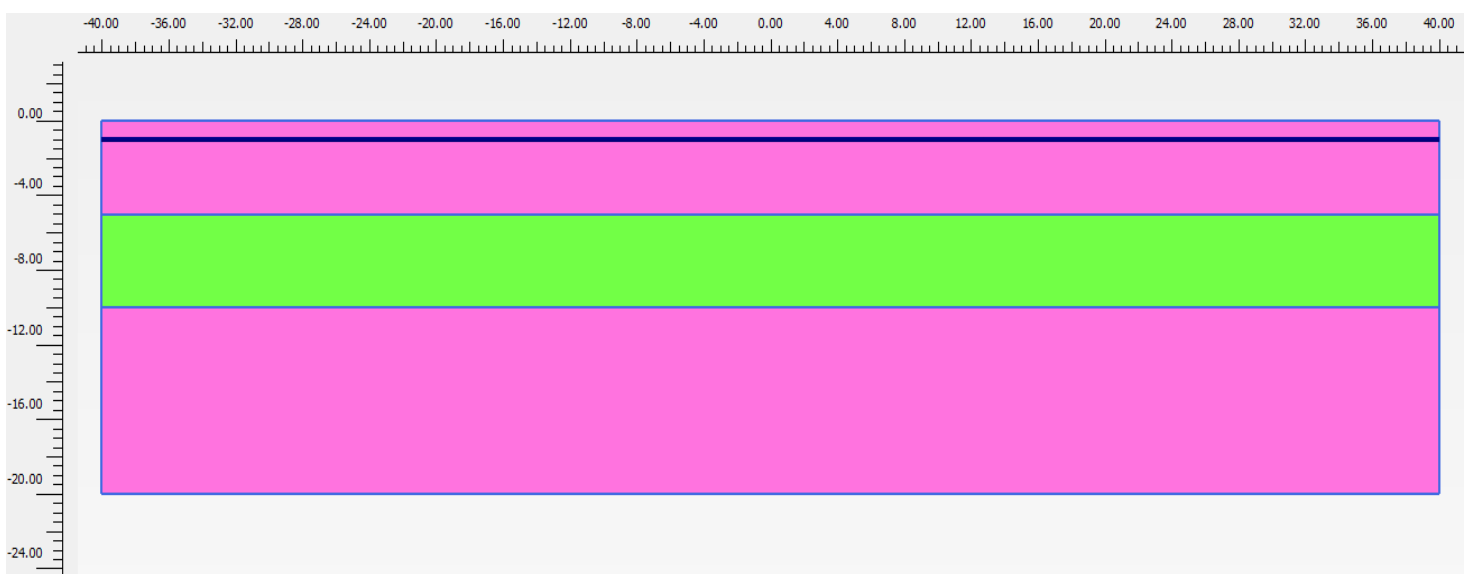

Fig . 2: Description of the case

\subsection{Description of earthquake}

There are three real types of earthquake 
used in this research.

\subsubsection{El Centro earthquake 1940}

The El Centro earthquake occurred on May 18 (1940) at 21:35 Pacific Standard Time (May 19 at 05:35 UTC) in the Imperial Valley in southeastern Southern
California. It had a moment magnitude of $\mathrm{Mw}=6.9$ and local magnitude $\mathrm{Ml}=5.9$ (Richter scale) (VDC), with a maximum perceived intensity of $\mathrm{X}$ (Extreme) on the Mercalli intensity scale. The time history of the El Centro earthquake is shown in Fig. (3) [14].

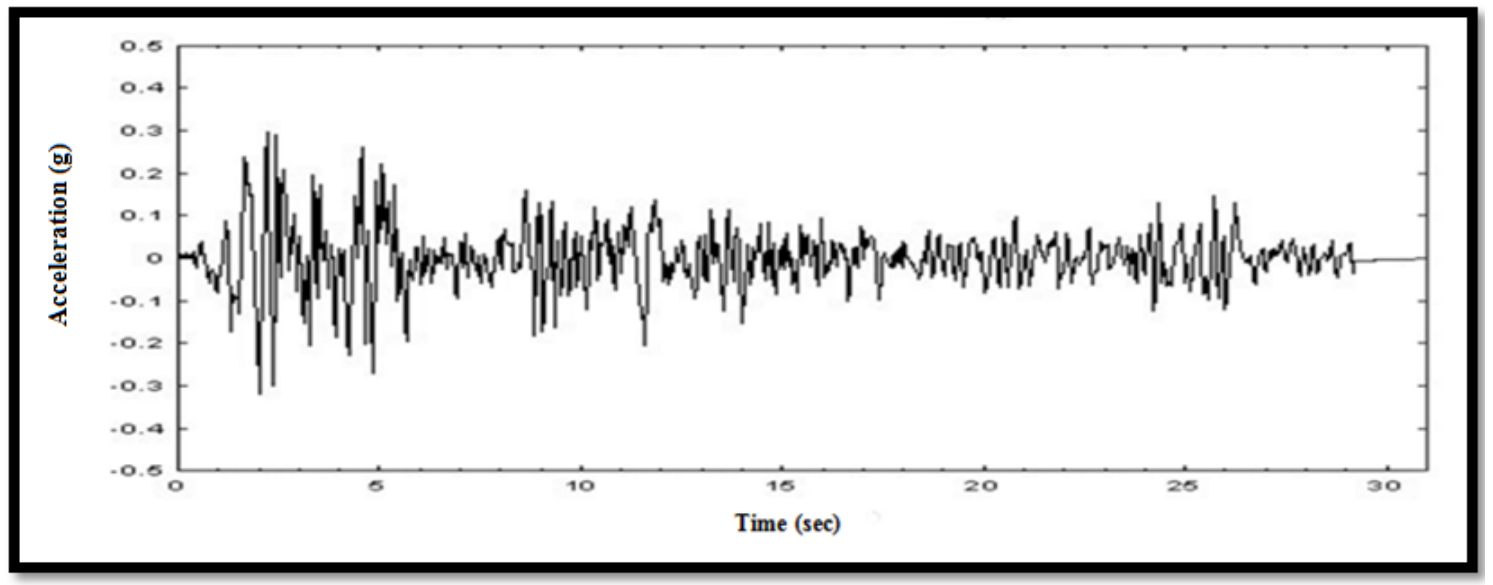

Fig . 3: Time history of the El Centro earthquake acceleration (USGS) [14].

\subsubsection{Imperial Valley earthquake 1979}

The Imperial Valley earthquake occurred on October 15 (1979) at 16:16 Pacific Daylight Time (23:16 UTC) just south of the Mexico-United States border. It had a moment magnitude of $\mathrm{Mw}=$
6.5 and local magnitude $\mathrm{Ml}=5.6$ (Richter scale) (VDC), with a maximum perceived intensity of IX (Violent) on the Mercalli intensity scale. The time history of the The Imperial Valley earthquake is shown in Fig. (4) [14].

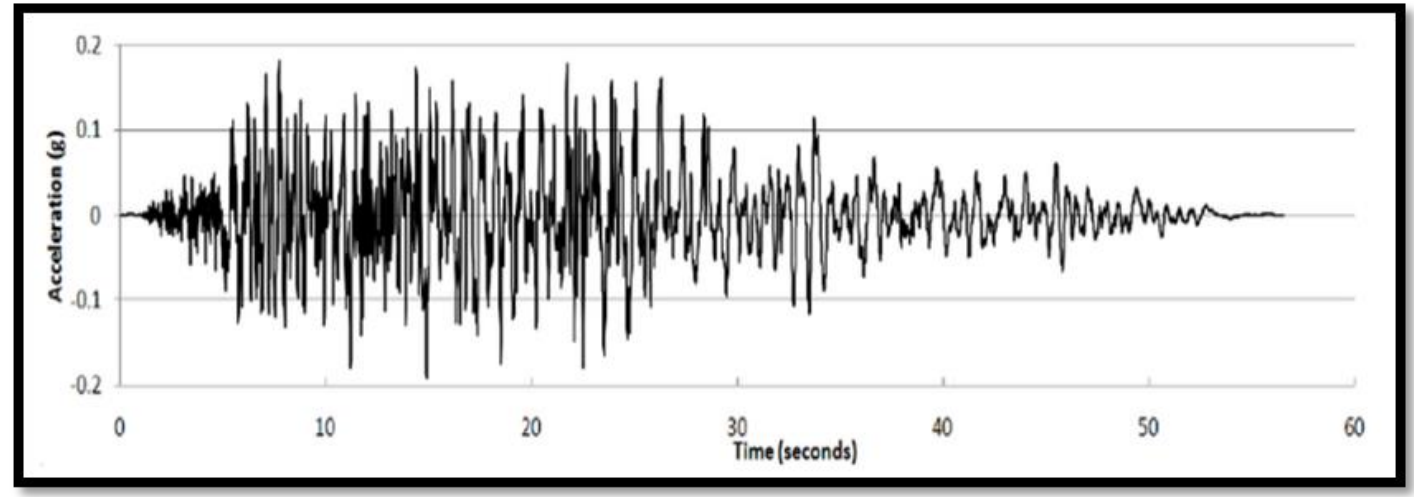

Fig . 4: Time history of the Imperial Valley earthquake acceleration (USGS) [14].

\subsubsection{Upland earthquake 1990}

The Upland earthquake occurred on February 28 at 23:43 local time ( UTC). This left-lateral strike-slip earthquake occurred west of the San Andreas Fault. The upland earthquake occurred with a moment magnitude of $\mathrm{Mw}=5.7$ and local magnitude $\mathrm{Ml}=5.2$ (Richter scale) ( VDC ) The time history of the Upland earthquake shown in Fig. (5) [14]. 


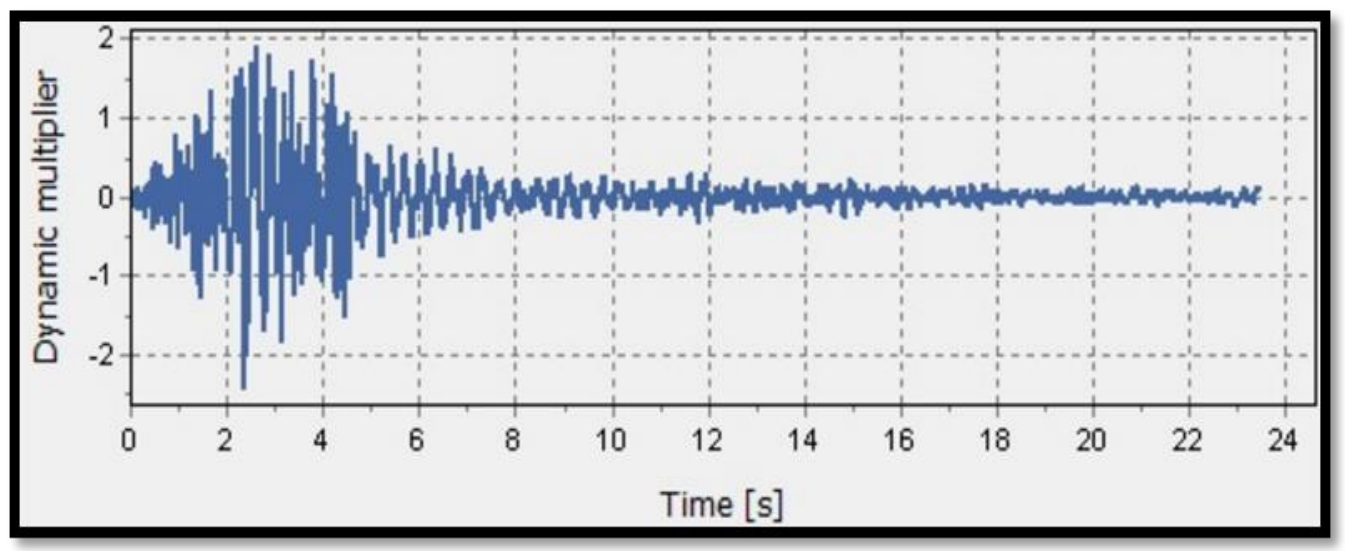

Fig : 5:- The time history of the Upland earthquake acceleration (USGS) [14].

\subsection{Material parameters}

3.2.1. Liquefied sand layer parameters

This research describes the liquefied sand by using the UBC3D-PLM model, the parameters value which use in this model are:-

- The value of the corrected stander penetration test (SPT) of the soil

$\left(\left(\mathrm{N}_{1}\right)_{60}\right)=10.65$

- Constant volume friction angle of the soil $\left(\Phi_{\mathrm{cv}}\right)=22^{\circ}$
- $k_{G}^{e}=21.7 \times 20.0 \times$

$$
(10.65)^{0.333}=954.1
$$

$k_{B}^{e}=954.1 \times 0.7=667.9$

- $k_{G}^{P}=954.1 \times(10.65)^{2} \times$

$$
0.003+100.0=424.7
$$

- $\Phi_{p}=22+\frac{10.65}{10}=23^{\circ}$

- $R_{f}=1.1 \times(10.65)^{-0.15}=$

$$
0.77
$$

$$
\mathrm{PA}=100 \mathrm{kPa}\left(\mathrm{K}_{\mathrm{e}}^{\mathrm{G}}\right)
$$


Table. 1: The input parameters of liquefied sand layer of the UBC3D-PLM model.

\begin{tabular}{|c|c|c|c|}
\hline Parameters & Symbol & Unit & Value in applied model \\
\hline Depth & - & $\mathrm{m}$ & $0: 20$ \\
\hline Type of soil & - & - & Silty sand to fine sand \\
\hline Young modulus & $\mathrm{E}_{\text {ref }}$ & $\mathrm{kN} / \mathrm{m}^{2}$ & $7.28 * 10^{4}$ \\
\hline Poisson's ratio & $\mathrm{v}$ & - & 0.3 \\
\hline Unit weight & $\gamma_{\text {unsat }}$ & $\mathrm{kN} / \mathrm{m}^{3}$ & 19.7 \\
\hline Saturated unit weight & $\gamma_{\text {sat }}$ & $\mathrm{kN} / \mathrm{m}^{3}$ & 21.8 \\
\hline Void ratio & $\mathrm{e}_{\mathrm{int}}$ & - & 0.7400 \\
\hline $\begin{array}{l}\text { Constant volume } \\
\text { friction angle }\end{array}$ & $\varphi_{\mathrm{cv}}$ & $\left({ }^{\mathrm{o}}\right)$ & 22 \\
\hline Peak friction angle & $\varphi_{p}$ & $\left({ }^{\circ}\right)$ & 23 \\
\hline Cohesion & $\mathrm{C}$ & $\mathrm{kpa}$ & 0 \\
\hline Elastic shear modulus & $\mathrm{k}_{\mathrm{G}}^{\mathrm{e}}$ & - & 954.1 \\
\hline Elastic bulk modulus & $\mathrm{k}_{\mathrm{B}}^{\mathrm{e}}$ & - & 667.9 \\
\hline Plastic shear modulus & $\mathrm{k}_{\mathrm{G}}^{\mathrm{p}}$ & - & 424.7 \\
\hline Elastic shear modulus index & $\mathrm{n}_{\mathrm{e}}$ & - & 0.50 \\
\hline $\begin{array}{l}\text { Elastic bulk modulus } \\
\text { Index }\end{array}$ & $\mathrm{m}_{\mathrm{e}}$ & - & 0.50 \\
\hline Plastic shear modulus index & $\mathrm{n}_{\mathrm{p}}$ & - & 0.50 \\
\hline Failure ratio & $\mathrm{R}_{\mathrm{f}}$ & - & 0.771 \\
\hline Atmospheric pressure & $\mathrm{P}_{\mathrm{A}}$ & - & 100 \\
\hline Tension cut-off & $\sigma_{\mathrm{t}}$ & $\mathrm{kpa}$ & 0.00 \\
\hline Densification factor & $\mathrm{Fac}_{\text {hard }}$ & - & 0.45 \\
\hline Corrected SPT value & $\left(\mathrm{N}_{1}\right)_{60}$ & - & 10.65 \\
\hline $\begin{array}{l}\text { Post liquefaction } \\
\text { Factor }\end{array}$ & $\mathrm{Fac}_{\text {post }}$ & - & 0.20 \\
\hline Permeability & $\mathrm{K}$ & $\mathrm{m} / \mathrm{s}$ & $2 * 10^{-7}$ \\
\hline Tangent stiffiness for oedometer & $\mathrm{E}_{\mathrm{oed}}$ & $\mathrm{kpa}$ & 98000 \\
\hline color & - & - & \\
\hline
\end{tabular}

\subsubsection{Strong sandy layer parameters}

This research describes the sandy soil(coarse sand) by using (HSSMALL) model.

- The value of the corrected stander penetration test (SPT) of the soil

$\left(\left(\mathrm{N}_{1}\right)_{60}\right)=23$

- Constant volume friction angle of the soil $\left(\Phi_{\mathrm{cv}}\right)=34^{\circ}$

- The value of the Secant stiffness in standard drained triaxial test $\mathrm{E}^{\mathrm{ref}}{ }_{50}=28000$ $\mathrm{kN} / \mathrm{m}^{2}$

- The value of the Tangent stiffness for primary oedometer loading $E_{\text {oed }}^{\text {ref }}$ is: $E_{\text {oed }}^{r e f}=E_{50}^{r e f}=28000 \mathrm{kN} / \mathrm{m}^{2}$
- The value of The Unloading / reloading stiffness $E_{u r}^{r e f}$ is :-

$$
E_{u r}^{r e f}=3 \times E_{50}^{r e f}=84000 \mathrm{kN} / \mathrm{m}^{2}
$$

- $\quad \mathrm{G}_{0}=\rho\left(\mathrm{v}_{\mathrm{s}}\right)^{2}=\frac{19.6}{9.81}(200)^{2}=$ $79918.45 \mathrm{kN} / \mathrm{m}^{2}$

- $\sigma 3=\Sigma(\gamma \times h)=90.9 \mathrm{kN} / m^{2}(9)$

- $G_{0}{ }^{r e f}=G_{0} \div\left(\frac{\sigma 3}{p}\right)^{m}=79918.45 \div$ $\left(\frac{90.9}{100}\right)^{0.5}=83823.4 \mathrm{kN} / m^{2}$ 
Table: 2. The input parameters of strong sand layer of the HSSMALL model

\begin{tabular}{|c|c|c|c|}
\hline Parameters & Symbol & Unit & Value in applied model \\
\hline Depth & & $\mathrm{m}$ & $-5:-10$ \\
\hline Type of soil & & & Strong sandy \\
\hline Young modulus & $\mathrm{E}_{\text {ref }}$ & $\mathrm{kN} / \mathrm{m}^{2}$ & \\
\hline Poisson's ratio & $\mathrm{v}$ & - & 0.25 \\
\hline Unit weight & $\gamma_{\text {unsat }}$ & $\mathrm{kN} / \mathrm{m}^{3}$ & 17.0 \\
\hline Saturated unit weight & $\gamma_{\text {sat }}$ & $\mathrm{kN} / \mathrm{m}^{3}$ & 19.6 \\
\hline Void ratio & $\mathrm{e}_{\text {int }}$ & - & 0.35 \\
\hline Constant volume friction angle & $\varphi_{\mathrm{cv}}$ & $\left({ }^{\circ}\right)$ & 34 \\
\hline dilatancy angle & $\psi$ & $\left({ }^{\circ}\right)$ & 4 \\
\hline Cohesion & $\mathrm{C}$ & Kра & 0.5 \\
\hline Corrected SPT value & $\left(\mathrm{N}_{1}\right)_{60}$ & - & 23 \\
\hline $\begin{array}{l}\text { Plastic straining due to primary } \\
\text { deviatoric loading }\end{array}$ & $\mathrm{E}^{\mathrm{ref}}{ }_{50}$ & $\mathrm{kN} / \mathrm{m}^{2}$ & 28000 \\
\hline $\begin{array}{l}\text { Plastic straining due to primary } \\
\text { compression }\end{array}$ & $\mathrm{E}_{\mathrm{oed}}^{\mathrm{ref}}$ & $\mathrm{kN} / \mathrm{m}^{2}$ & 28000 \\
\hline Elastic unloading / reloading & $\mathrm{E}^{\mathrm{ref}} \mathrm{ur}$ & $\mathrm{kN} / \mathrm{m}^{2}$ & 84000 \\
\hline $\begin{array}{l}\text { Stress dependent stiffness according to } \\
\text { a power law modulus Index }\end{array}$ & $\mathrm{m}$ & - & 0.50 \\
\hline Permeability & $\mathrm{K}$ & $\mathrm{m} / \mathrm{s}$ & $1.3 * 10^{-5}$ \\
\hline Failure ratio & $R_{f}$ & - & 0.9 \\
\hline normal consolidation & $\mathrm{K}_{0}$ & - & 0.44 \\
\hline Atmospheric pressure & $\mathrm{p}^{\mathrm{ref}}$ & - & 100 \\
\hline shear wave velocity & $\mathrm{V}_{\mathrm{s}}$ & $\mathrm{m} / \mathrm{sec}$ & 200 \\
\hline Effective stress & $\sigma^{\prime} 3$ & $\mathrm{kN} / \mathrm{m}^{2}$ & 90.9 \\
\hline $\begin{array}{l}\text { The shear modulus at very small strain } \\
\text { level of sand layers }\end{array}$ & $\mathrm{G}_{0}$ & $\mathrm{kN} / \mathrm{m}^{2}$ & 79918.45 \\
\hline $\begin{array}{l}\text { The reference shear modulus at very } \\
\text { small strain level }\end{array}$ & $\mathrm{G}_{0}{ }^{\text {ref }}$ & $\mathrm{kN} / \mathrm{m}^{2}$ & 83823.4 \\
\hline shear strain level & $\gamma 0.7$ & - & $10^{-4}$ \\
\hline Color & & & \\
\hline
\end{tabular}

\section{Analysis of results}

This research demonstrates the analysis results obtained from the proposed models. This ground consists of strong (coarse sand) and liquefied sand layers in four cases as mentioned before. All cases are subjected to three types of earthquake. Six pore-water pressures are recorded by the program. Values range between 0 and $-15 \mathrm{~m}$ in depth. This research draws attention to the records points $(\mathrm{B}, \mathrm{D}$, and $\mathrm{F})$, these values for all inveigled cases. 
Journal of Advanced Engineering Trends (JAET), Vol. 38, No. 2. July 2019

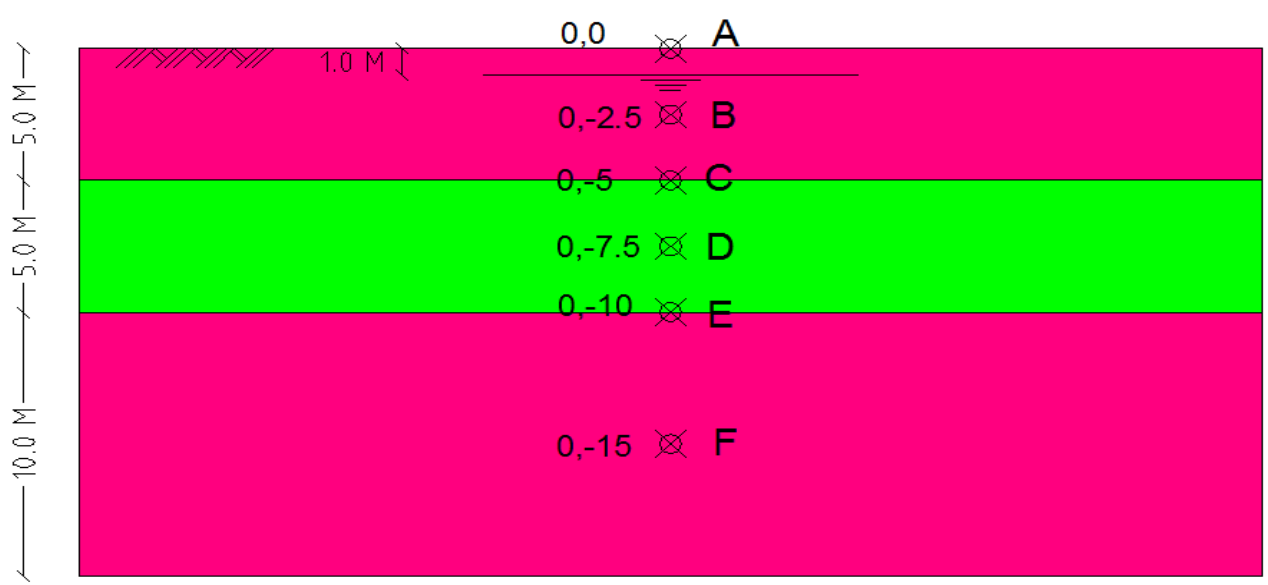

Fig . 6: Determination of instruments position in the model

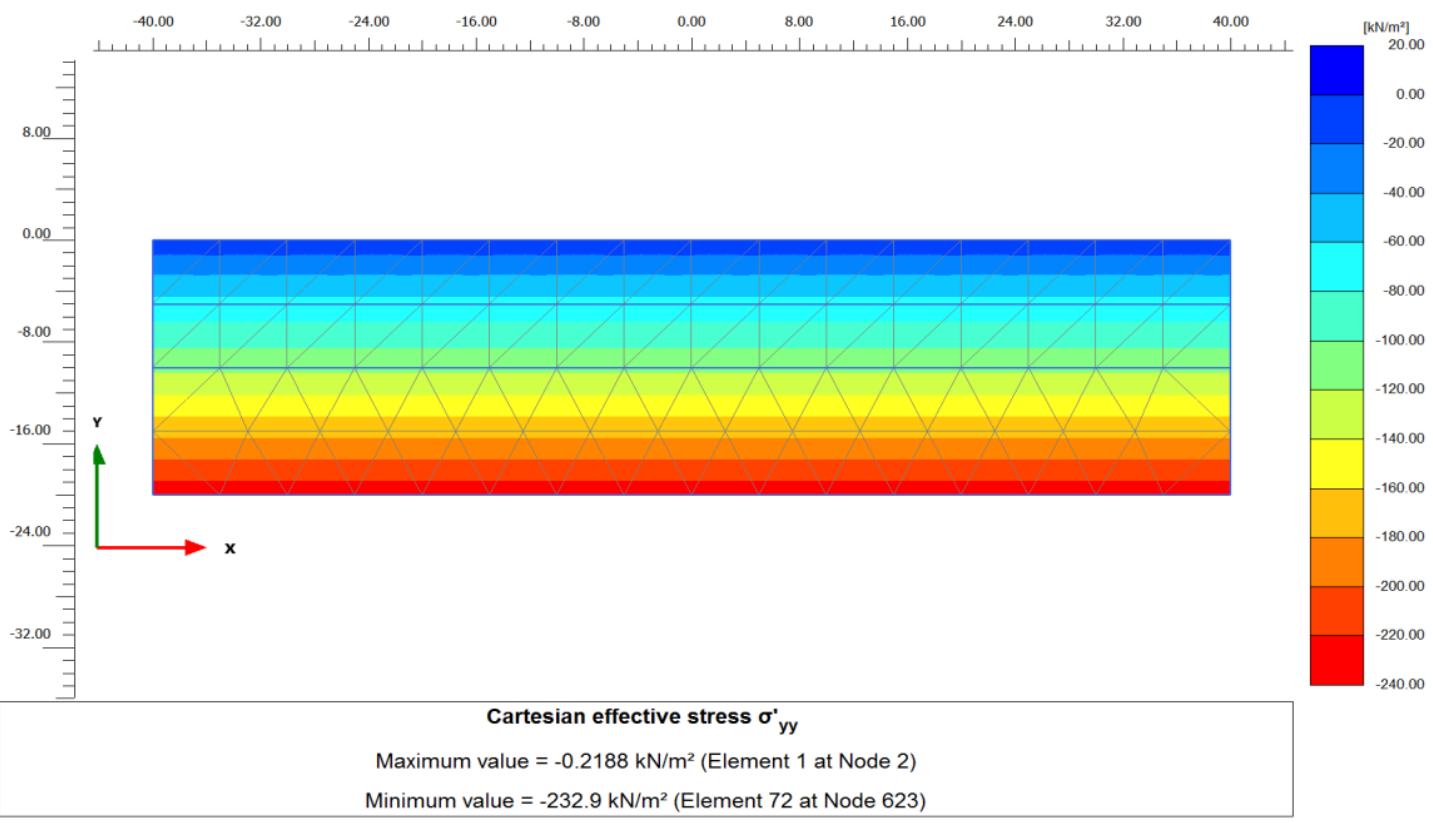

Fig . 7: Effective stress in $\mathrm{Y}$ axess before earthquake.

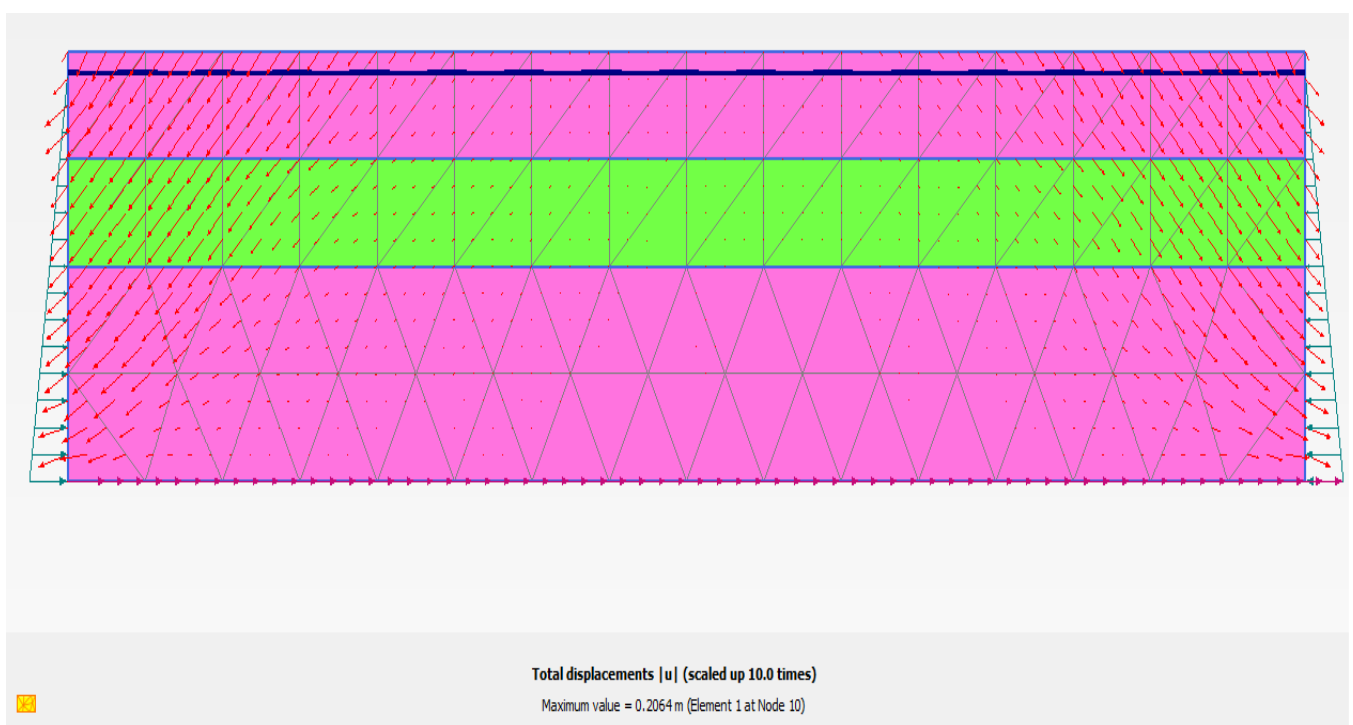

Fig . 8: Total displacement after Upland earthquake. 
For the three considered earthquake, excess pore pressure relationship with time are shown in Figures (9) to (11). It may be noted that points in liquefiable layers have greater pore pressure compared to nonliquified layers. Point (F) which lies at the lowest liquefied layer gets the maximum value of excess pore pressure. Point (B) which lies at the upper liquefied layer gets a high value of excess pore pressure but lower than point $(\mathrm{F})$. On other hand, Point (D) in the strong layer has a very small value of increase in excess pore pressure compared to Points (F) and (B). These observations are obvious for liquefied layer because it is more susceptible to pore pressure generation than layers.

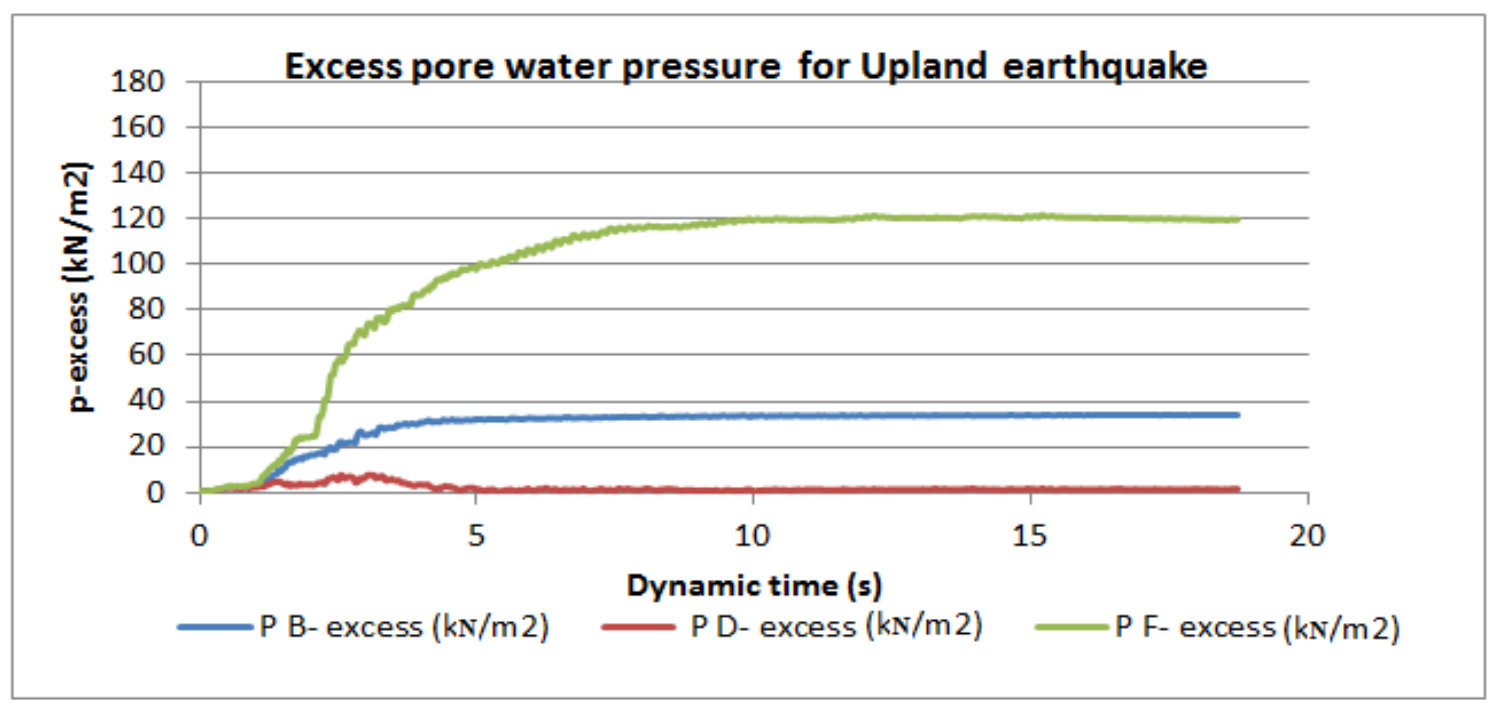

Fig . 9: Excess pore water pressure for Upland earthquake at points (B, D, and F).

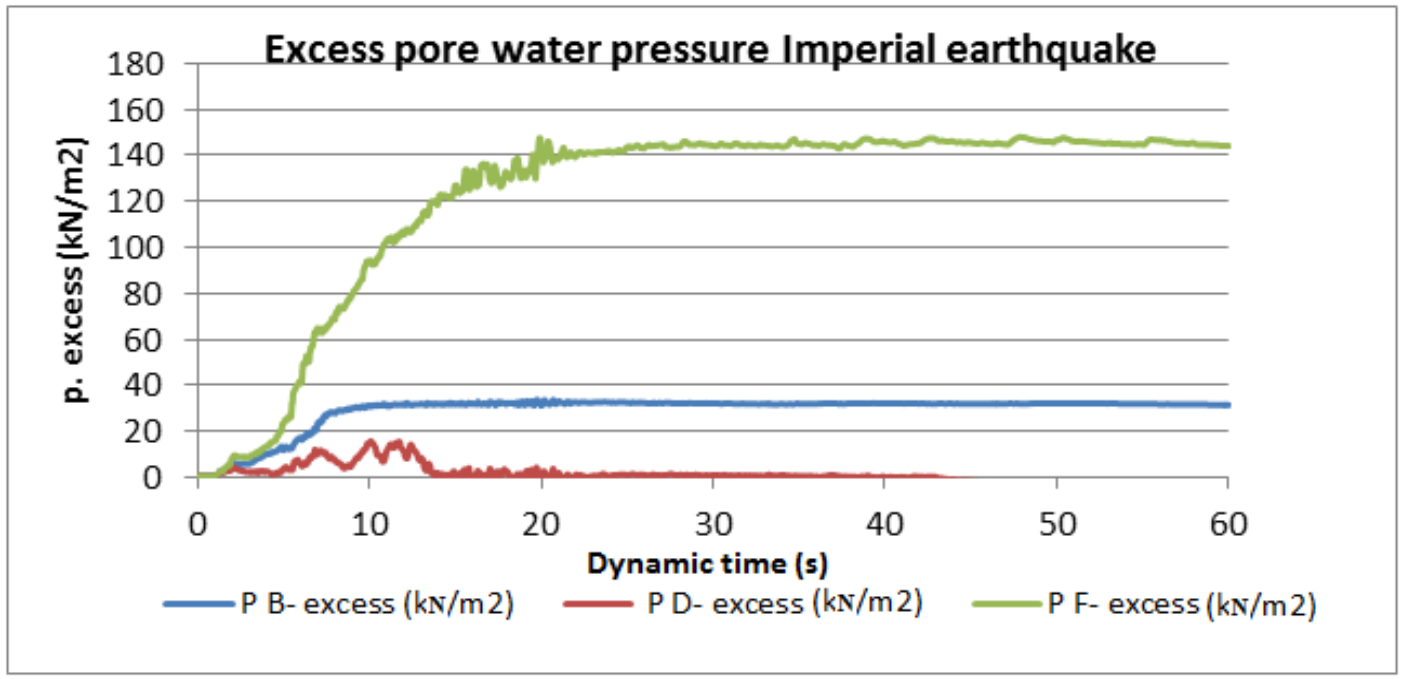

Fig. 10: Excess pore water pressure for Imperial earthquake at points (B, D, and F). 


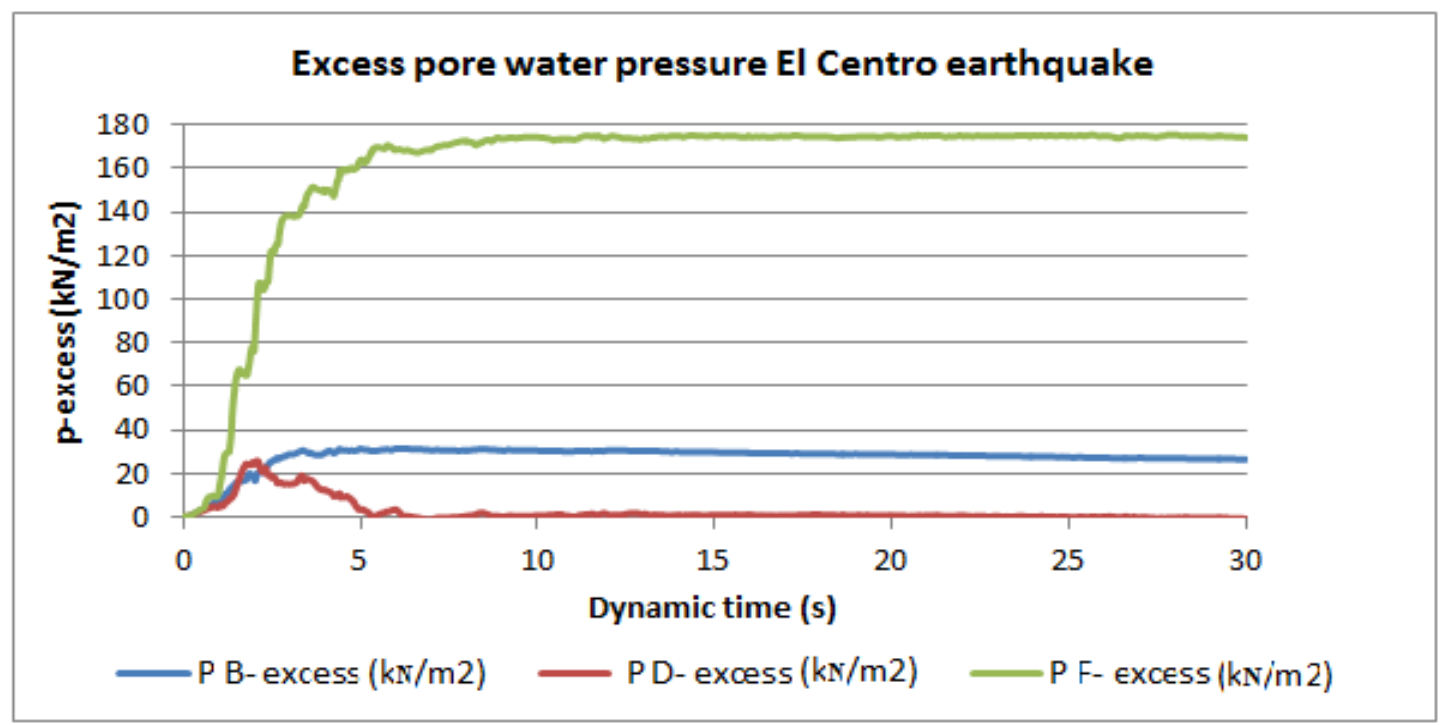

Fig : 11:- Excess pore water pressure for El Centro earthquake at points (B, D, and F).

For Upland earthquake, the following results are obtained (similar results are obtained for Elcentro earthquake and Imperial earthquake).

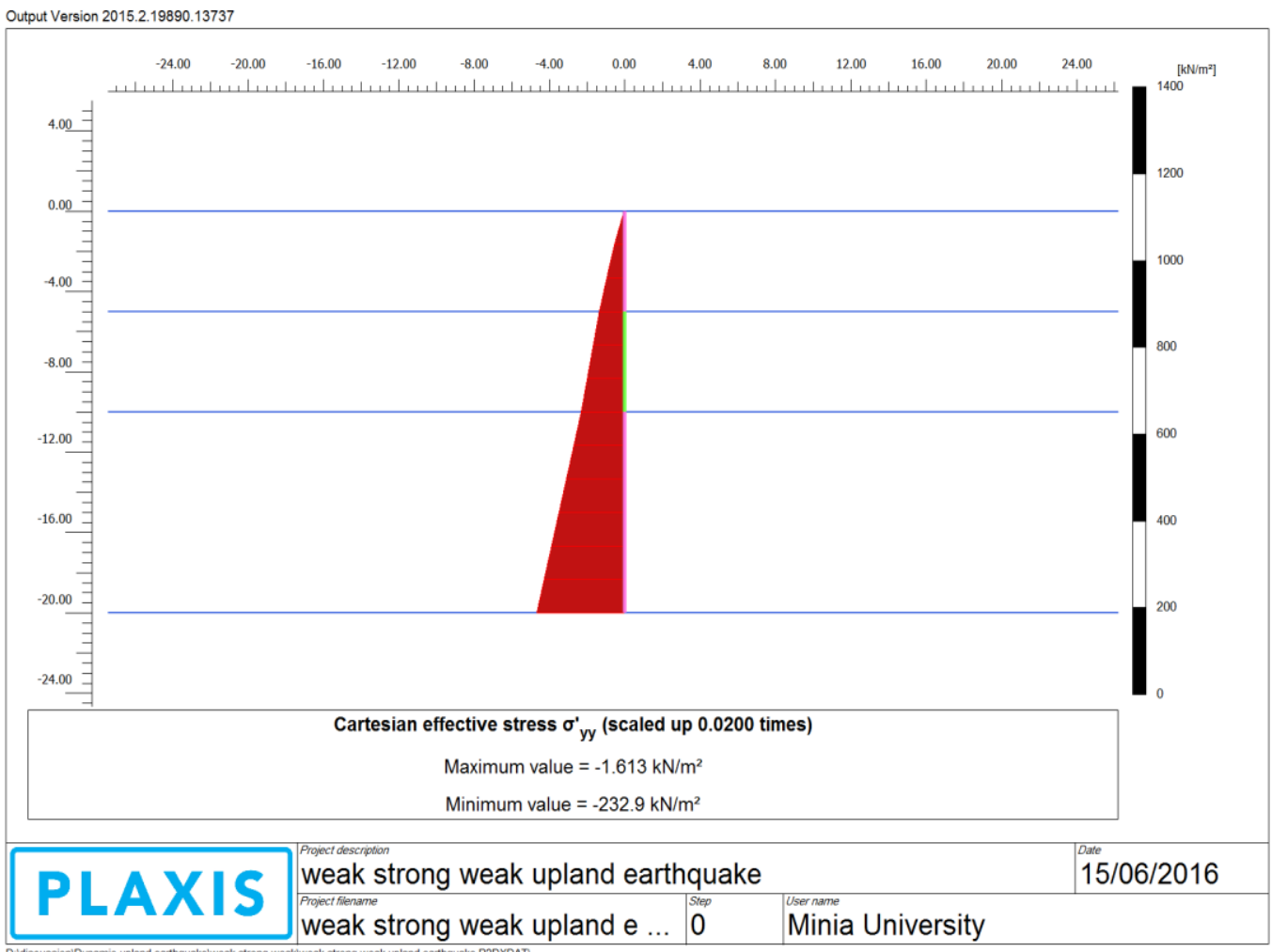

Fig . 12: Vertical effective stress distribution before earthquake effect. 
Journal of Advanced Engineering Trends (JAET), Vol. 38, No. 2. July 2019

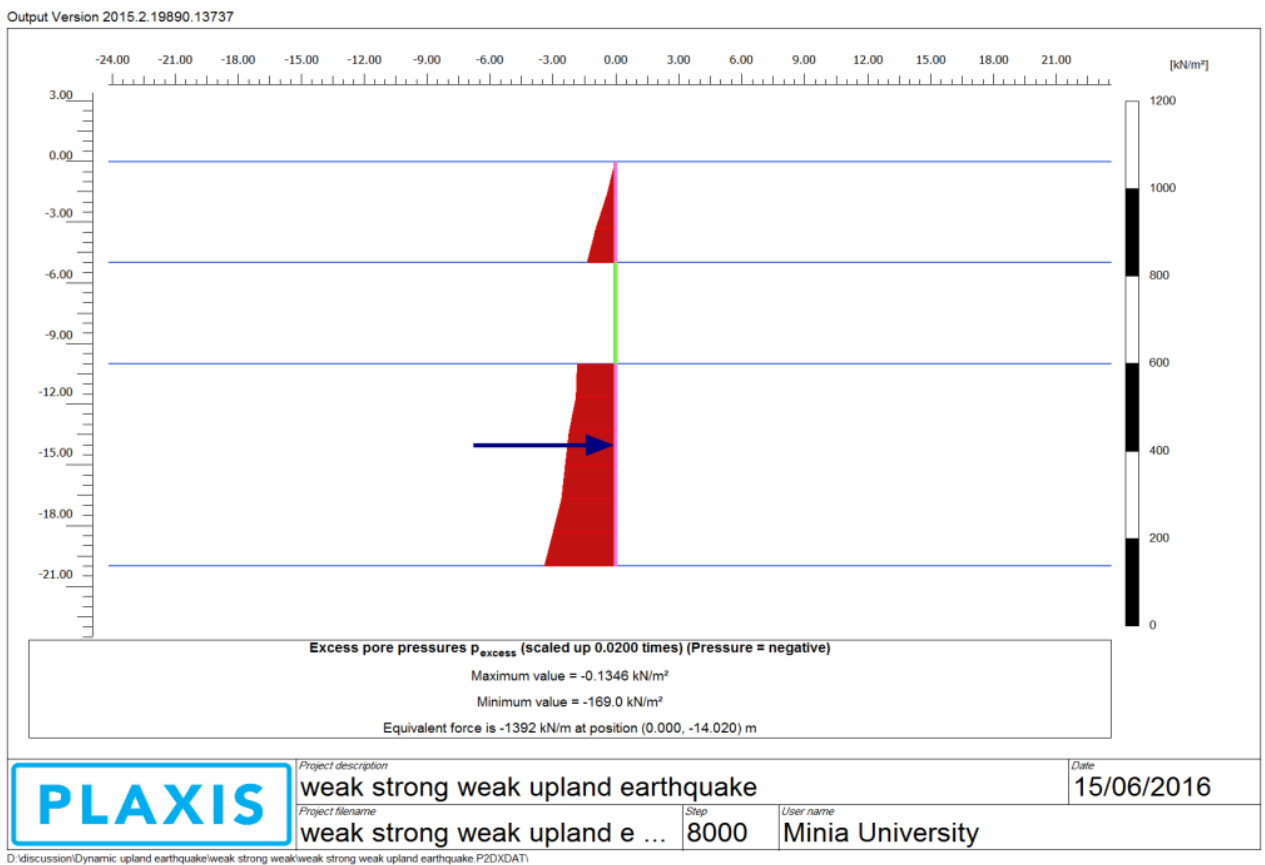

Fig. 13: Generation of excess pore water with depth at the end of Upland earthquake.

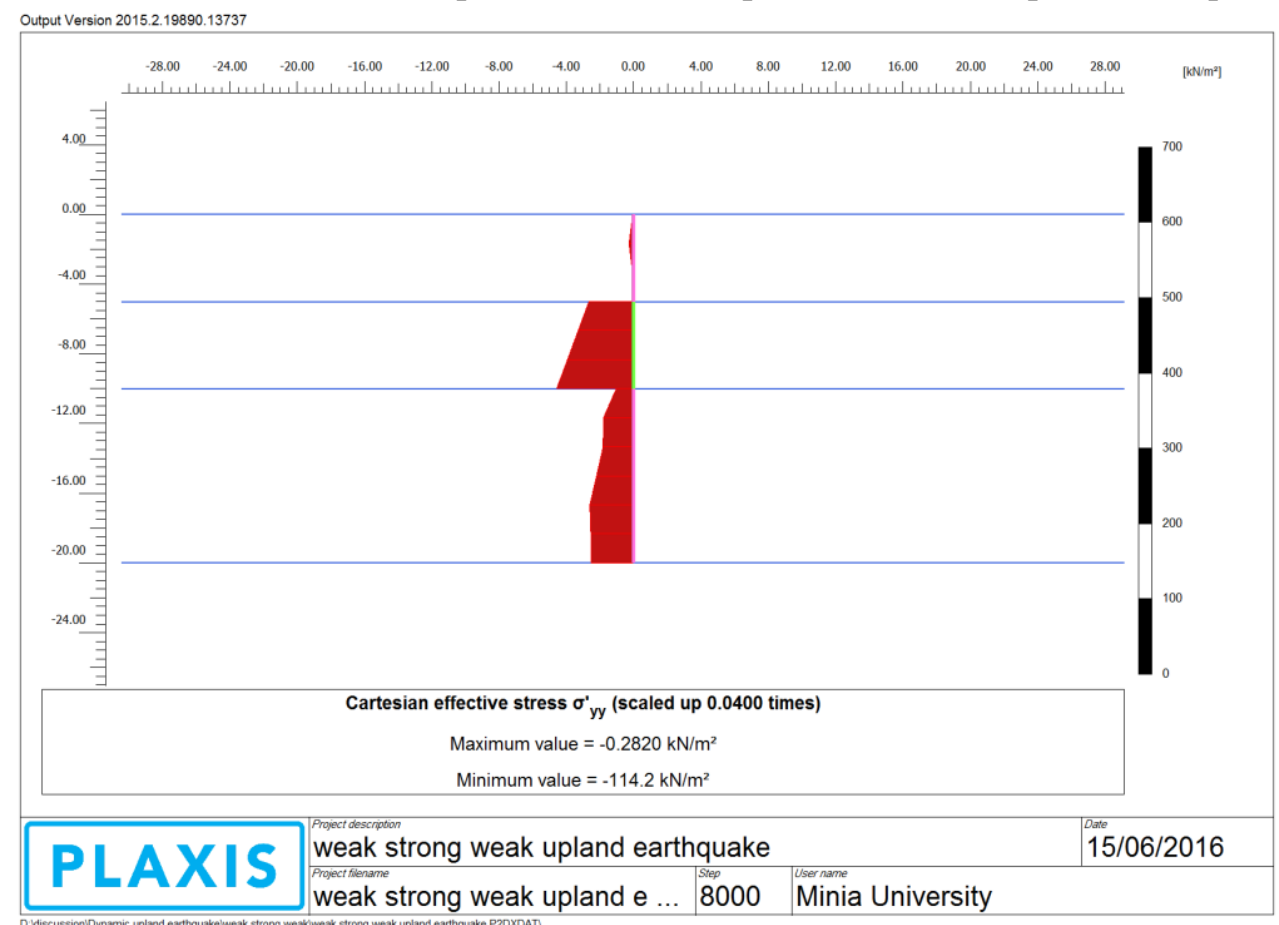

Fig. 14: Vertical effective stress distribution with depth at the end of Upland earthquake. 


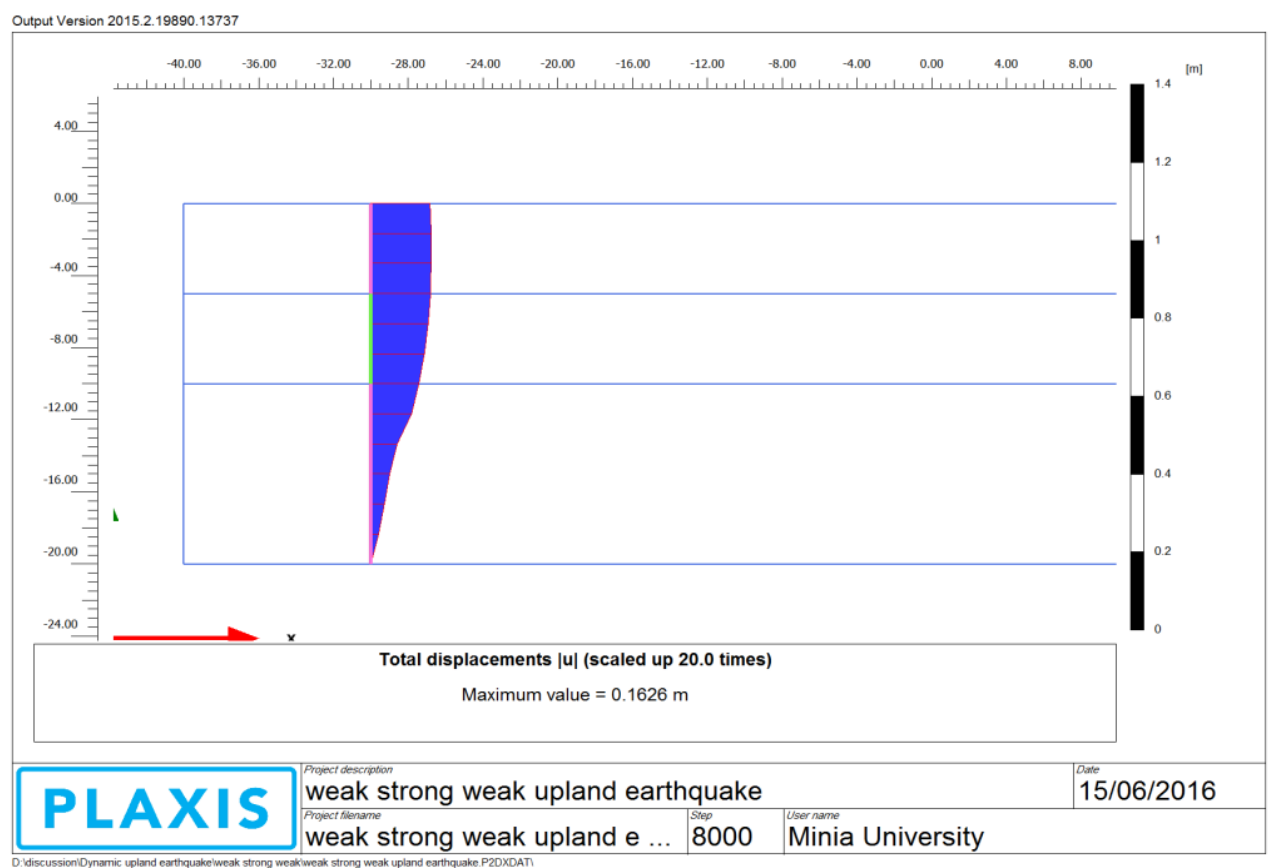

Fig. 15: Total displacement at cross section at the end of Upland earthquake.

Figure (12) shows the vertical stress distribution before earthquake effect. After earthquake effect, the increase in excess pore pressure is strong in upper liquefied layer and very strong in the lowest liquefied layer. But in the strong layer the value of excess pore pressure can be negligible as shown in Fig. (13). According to Figs. (12) and (13), the vertical effective stress distribution with depth at the end of Upland earthquake equal to the summation of vertical effective stress distribution before earthquake effect and the generation of excess pore water with depth at the end of Upland earthquake as shown in Fig. (14).

For Upland Earthquake, the relationship between shear strain and shear stress are shown in Figs. (16), (17), and (18).

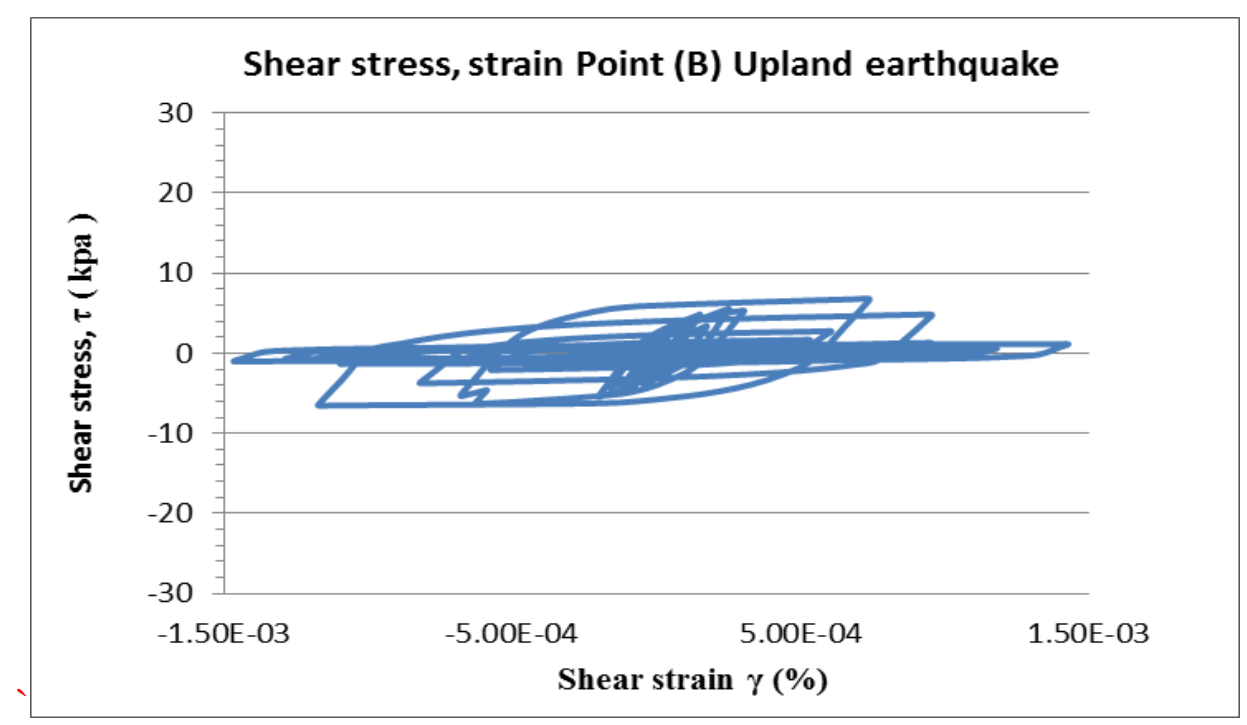

Fig . 16: Evolution of shear stress-strains history during undrained simple shearing at point (B). 


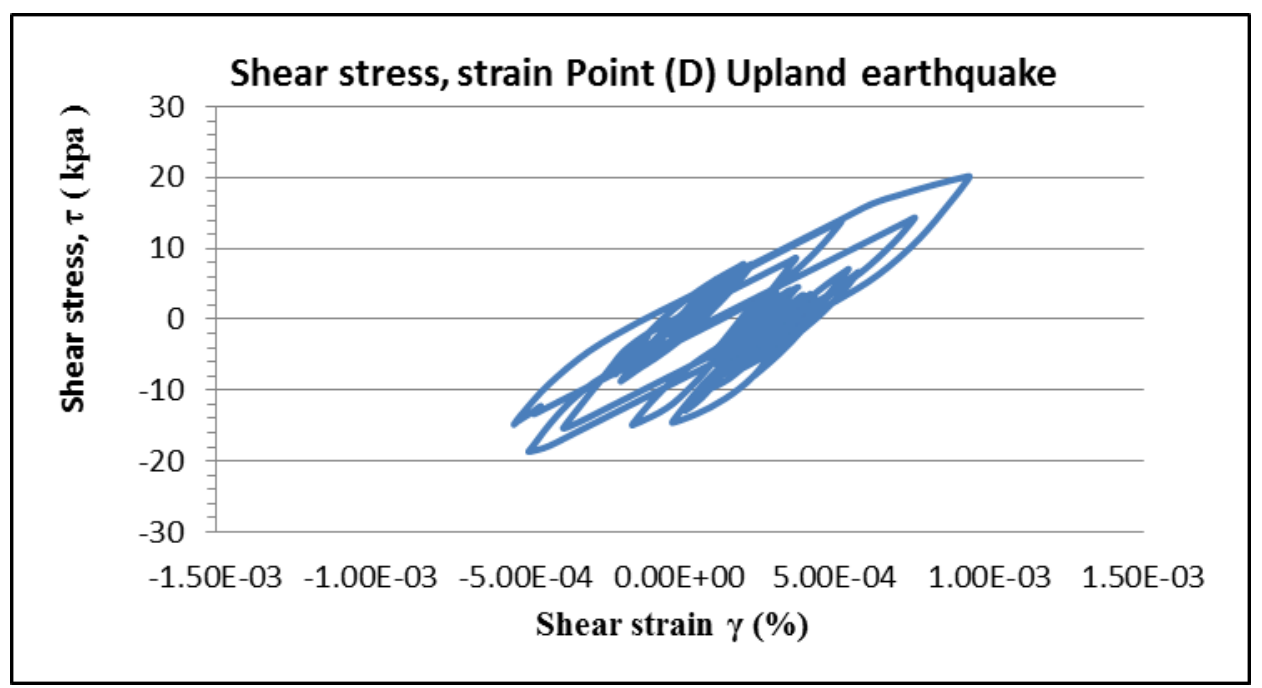

Fig . 17: Evolution of shear stress-strains history during undrained simple shearing at point (D).

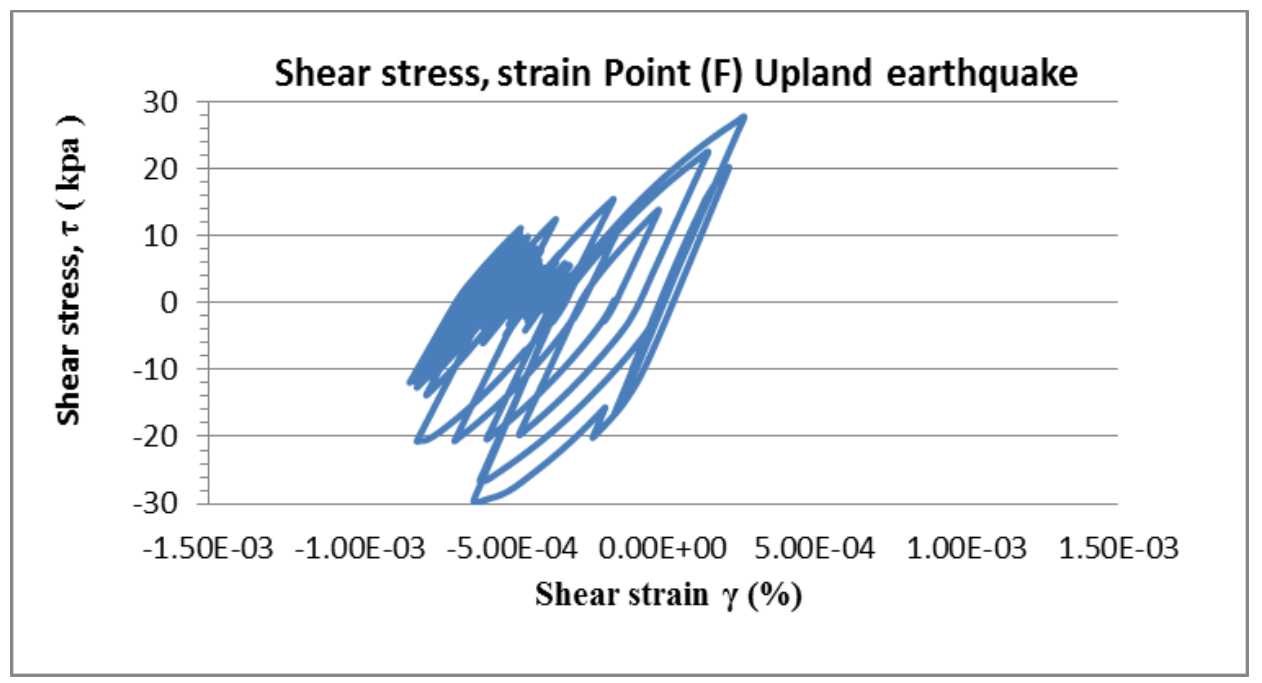

Fig. 18: Evolution of shear stress-strains during undrained simple shearing at point $(F)$.

Similar results are obtained for the other two earthquakes.

\section{Conclusion}

This paper provides an overview of the basic of PLAXIS in modeling dynamic problems, by using UBC3D-PLM constitutive model and HSSMALL model. The Upland, El Centro and Imperial earthquake case history is used in this study. For the cases studied in this research, the following conclusions may be drawn:

1- The presented model is capable of simulating the liquefaction phenomenon.
2- The UBC3D-PLM model proved to capture successfully the characteristics of soil liquefaction.

3- The model builds the main mechanisms (increasing excess porewater pressure) of liquefaction.

4- It is flexible and easy to use the UBC3D-PLM model (most of the material properties are related to SPT).

5- The Hardening Soil model with small-strain stiffness (HS small) proved to capture successfully the characteristics of sandy soil.

6- For the same soil layers, the earthquake type has a significantly 
effect on the value of excess porewater pressure.

7- Effective stress on the strong layer has a higher value than the liquefied layer after earthquake imposed.

\section{References}

[1] National Research Council (NRC), "Liquefaction of Soils During Earthquakes",Washington DC: National Academy Press, 1985.

[2] Binkgreve, R. B. J. B "Selection of Soil Models and Parameters for Geotechnical Engineering Application", J. Yamamuro, \& V. Kaliakin (Eds.), Geotechnical Special Publication, 128, pp.69-98, 2005.

[3] Schweiger, H. F. "The Role of Advanced Constitutive Models in Geotechnical Engineering", J. Geomechanics and Tunneling, 1(5), pp.336-344. 1981, 2008.

[4] Abbas Daftari, Wolfram Kudla, TU Freiberg, Stravros Savidis, TU Berlin, habil. Heinz Konietzky, TU Freiberg "New approach in prediction of soil liquefaction" Faculty of Geosciences, GeoEngineering and Mining of the Technische Universität Bergakademie Freiberg,2015

[5] Brinkgreve, R. B. J, Bakker, K.J., and Bonnier,“ The relevance of small-strain soil stiffness in numerical simulation of excavation and tunneling projects", In: H.F. Schweiger (ed.) Numerical Methods in Geotechnical Engineering. Taylor \& Francis. P.G .133-139. 2006.

[6] Beaty, M., and Byrne, P. "An effective stress model for predicting liquefaction behavior of sand", Geotechnical Earthquake Engineering and Soil
Dynamics III ASCE Geotechnical Special Publication No.75, 1:766-777, 1998.

[7] Beaty, M. and Byrne, P."UBCSAND constitutive model: Version 904aR", Documentation Report: UBCSAND Constitutive Model on Itasca UDM Web Site, Boulanger RW. Relating K_ to relative state parameter index. Journal of Geotechnical and Geoenvironmental Engineering, 2011; 129(8): 770-773. February 2011.

[8] Tsegaye. Plaxis liqueafaction model. report no. 1. PLAXIS knowledge base., 2010.

[9] Petalas, A., and Galavi, V. "PLAXIS Liquefaction Model UBC3D-PLM", Retrieved from PLAXIS Website: http://kb.plaxis.nl/models/udsmubcsand 3d- model. 2013.

[10] Schanz, T., Vermeer, P. A., and Bonnier, P. G. "The hardening soil model: formulation and verification", Beyond 2000 in Computational Geotechnics, Balkema, Rotterdam, 1999.

[11] Duncan, J. M. and Chang, C. $\mathrm{Y}$,"Nonlinear analysis of stress and strain in soils", Journal of the Soil Mechanics and Foundations Division, ASCE, Vol. 96, pp. 1629-1653, 1970.

[12] Benz,"Small-strain stiffness of soil and its numerical consequences", Ph.D. Thesis, University Stuttgart. T, 2006.

[13] Hardin, B.O., Drnevich, "Shear modulus and damping in soils: Design equations and curves", Proc. ASCE: Journal of the Soil Mechanics and Foundations Division, 98(SM7), 667-692,1972

[14] USGS Description of the El Centro , Imperial Valley and Upland Earthquake and (strong-motion Virtual Data Center( VDC)) 


\section{UBC3D-PLM التحليل العددى لظاهرة أسالة الترية عن طريق النموذج التكوينى}

الملخص العربي:

اسالة التربة ( التميع ) هي ظاهرة تحدث للتربة المشبعة غير المتماسكة تحت الظروف غير المصرفة عند حدوث زلزال او اي حمل متكرر ينتج عنها نقص ملحوظ في جساءة و مقاومة التربة للاحمل و ينتج عنه حدوث ضغط مسامي زائد تحت ظروف التحميل غير المصرف. الماء الموجود بالتربة يحدث ضغط علي جزيئات التربة يؤدي الي تكثثف جزيئات التربة و قبل حدوث الزلزال يكون ضغط الماء منخفض نسبيا ومع ذلك، يمكن أن يؤدي اهتزاز الزلزال إلى زيادة ضغط الماء إلى إلى النقطة

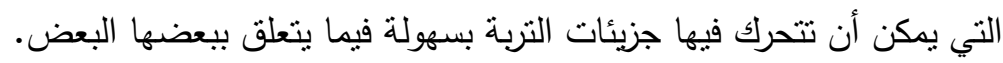

في هذا البحث ثم استخدام برنامج UDC3D-PLM عن طريق النموذج التكويني لدراسة تاثير ظاهرة التميع

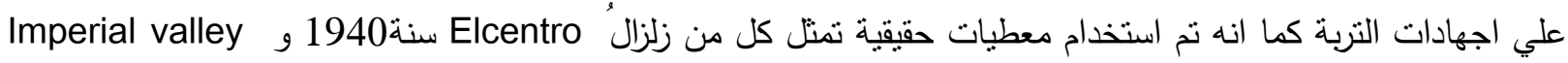
سنة Upland سنة1979 و زلزال 1990 ـو استخدم هذا البحث ليقارن بين ناثير الزلازل المختلفة علي الرمال المسالة و التربة الرملية المتماسكة .

وقد نم التوصل من هذا البحث الا ان النموذج التكويني قادر علي تمثيل ظاهرة التميع لما نم التوصل به من نتائج تمثل الواقع ، كما انه تمت المقارنة بين سلوك التربة المسالة و التربة الرملية اثثاء حدوث الزلزال و مدي تأثر كلا منهما بالزلزال . من لجن 